\title{
Understory Species Diversity, Regeneration and Recruitment Potential of Sacred Groves in South West Nigeria
}

\section{J. C. Onyekwelu}

Federal University of Technology Akure School of Agriculture and Agricultural Technology

\section{A. Lawal ( $\square$ alawal@futa.edu.ng )}

Federal University of Technology Akure School of Agriculture and Agricultural Technology

R. Mosandl

Technische Universitat Munchen

B. Stimm

Technische Universitat Munchen

\section{A. D. Agbelade}

Ekiti State University Faculty of Agricultural Science

\section{Research}

Keywords: Ecological indicators, natural regeneration, biodiversity conservation, ecosystem services

Posted Date: August 4th, 2020

DOl: https://doi.org/10.21203/rs.3.rs-49207/v1

License: (9) This work is licensed under a Creative Commons Attribution 4.0 International License. Read Full License 


\section{Understory Species Diversity, Regeneration and Recruitment Potential of Sacred Groves in South West Nigeria}

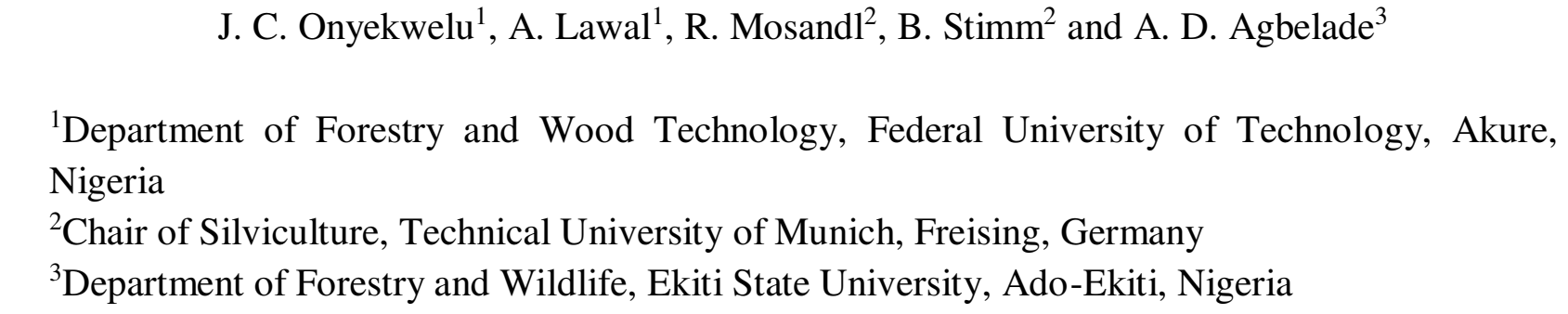

Global species extinction rates due to forest conversions are increasing. Ecologists, conservationists and governments have adopted various conservation methods. Sacred grove is one conservation option that has gained attention in recent time. We assessed understory species diversity, regeneration and recruitment potentials of four sacred groves in southwestern Nigeria. Overstory tree species were inventoried in eight $800 \mathrm{~m}^{2}$ temporary sample plots, systematically laid along two transects of $1000 \mathrm{~m}$ each. Understory tree species were assessed in $100 \mathrm{~m}^{2}$ plots for saplings and $25 \mathrm{~m}^{2}$ plots for seedlings in all sample plots.

\section{Results}

Shannon-Wiener diversity index (1.8-3.46 (overstory); 2.65-3.55 (understory)), number of species (32-58 (overstory); 39-78 (understory)) and tree density (309-417 individuals/ha (overstory); 775-1445 individuals/ha (understory)) were comparable and/or higher at the understories than the overstories. Dbh distribution curves showed highest stand density at the 7 lowest class $(10-20 \mathrm{~cm})$ and decreased with increasing dbh, indicating good regeneration status 8 and healthy ecosystem. Regeneration was considered good and fair, because in most cases, 
number of seedlings $>$ saplings $>$ overstory trees or number of seedlings $>$ saplings $\leq$ overstory trees. The good regeneration status was further confirmed by the good species recruitment in the understory. Some tree species were found to be unique to some sacred groves while some species

32 that were absent in protected forests existed in the groves. The presence of these unique tree 33 species indicated the potential of sacred groves in conserving important tree species. The high 34 regeneration could be attributed to strict access restrictions in the groves, and the taboos and 35 myths feared by the people. However, the high influx of people into sacred groves for festivals 36 and rituals, which results in trampling and burning of seedlings, is a threat to the diversity, 37 regeneration and recruitment potentials of the groves.

\section{Conclusion}

39 High regeneration and recruitment status maintained in all the sacred groves in this study were achieved using taboos, cultural and traditional methods. These methods could be incorporated in

41 managing forest reserves in Southwestern Nigeria.

42 Keywords: Ecological indicators, natural regeneration, biodiversity conservation, ecosystem 43 services

\section{Introduction}

45 Biodiversity is essential for the wellbeing of the ecosystem but the escalating extinction crisis 46 shows that the diversity of nature can no longer support the current pressure that humanity exerts 47 on the forest (Shushma et al., 2015). High density and diversity of species in rainforests have 48 attracted incessant disturbance of the ecosystem through high harvesting pressure (both legal and 49 illegal) (Onyekwelu et al., 2008). Species extinction rate is increasing, reaching up to 1,000 50 times or more than the natural rate because of habitat destruction, land conversion for agriculture 51 and development, climate change, pollution and the spread of invasive species (Shushma et al., 
52 2015). Consequently, ecologists, conservationists and governments have recommended and

53 adopted various conventional and traditional conservation methods. One of the methods that

54 have gained attention in the recent past is the use of traditional practices in protecting and

55 managing biodiversity, among which the sacred grove system is prominent (Daye and Healey,

56 2015). In Nigeria and elsewhere, sacred groves have been observed to play important role in

57 biodiversity conservation (Bhagwat and Rutte, 2006; Khan et al., 2008; Kokou et al., 2008;

58 Onyekwelu and Olusola, 2014). Many studies have assessed the forest population, structure and

59 biodiversity conservation potentials of the overstory layers of sacred groves in Nigeria

60 (Onyekwelu and Olusola 2014; Salami and Akinyele, 2018; Ikyaagba et al., 2019). However,

61 studies on understory tree species diversity in sacred groves are rare while no known study has

62 assessed the regeneration and recruitment potentials of sacred groves in Nigeria.

63

64 The forest understory is an integral component of the forest ecosystems, thus it demands as much

65 attention as the overstory. Ecologically, understory tree species play a fundamental role in

66 diversity, structure, and functioning of forest ecosystems (Svenning, 2000). They support a large

67 fraction of total community floristic diversity and provide habitats and food for many kinds of

68 animals (Tchouto et al., 2006). The forest understory plays a central role in the dynamics of

69 forest ecosystems by influencing long-term successional patterns and contributing to forest

70 nutrient cycles (Chastain et al., 2006). It has been suggested that the forest understory may show

71 different patterns of species diversity than the overstory due to different responses to light level,

72 nutrient availability, and temperature (Svenning, 2000) and could be as species-rich as the forest

73 overstory (Tchouto et al., 2006) or even richer. 
74 Sacred groves have been noted to harbour many commercially important and highly valuable

75 tree species, they are religio-culturally and socio-economically important to their communities,

76 hence their sustainability is key to their host communities (Onyekwelu and Olusola, 2014;

77 Adeyanju, 2020). But today, they are confronted with anthropogenic infringement and hence the

78 task of finding suitable strategies to enhance regeneration and species recruitment. Regeneration

79 is a biological process which involves asexual and sexual reproduction, dispersal and

80 establishment (Barness, 1997), successful regeneration and vigorous height growth lead to

81 recruitment. In silviculture, recruitment is a process by which trees move from one size class to

82 another (Helms, 1998) or by which young trees overgrow certain threshold values of height or

83 diameter (Lexerod and Eid, 2005). Greene et al. (1999) listed the factors that could influence the

84 density and composition of seedlings in forest ecosystems to include: site conditions, seed rain

85 and seed banks, light conditions, competition, intra- and inter-species relations.

86 Regeneration of forest trees is essential for conservation and maintenance of biodiversity in

87 forest ecosystems as well as for forest management. The knowledge of plant regeneration status

88 helps in developing management options and setting priorities. Limited tree regeneration is a

89 major threat to forest sustainability. The satisfactory natural regeneration behaviour of the forests

90 depends on population structure characterized by the production and germination of seed,

91 establishment of seedlings and saplings in the forest (Khumbongmayum et al., 2006). Complete

92 absence of tree seedlings and saplings in a forest indicates poor regeneration, while presence of

93 sufficient number of seedlings indicate successful regeneration (Saxena and Singh 1984).

94 Despite the biodiversity conservation merits of sacred groves and the importance of regenerates

95 in sustaining and maintaining biodiversity, studies on tree species regeneration status in Nigerian

96 sacred groves are are lacking. Therefore, an attempt was made in this study to fill this knowledge 
97 gap. Consequently, this study investigated the understory tree species diversity, regeneration and recruitment potential of sacred groves in southwestern Nigeria.

\section{Methodology}

100 The study was carried out in southwestern region of Nigeria made up of six federal states of 101 Lagos, Ogun, Oyo, Osun, Ekiti and Ondo. The region lies between longitude $2^{0} 31^{\prime}$ and $6^{0} 00^{\prime}$ 102 East and Latitude $6^{0} 21^{\prime}$ and $8^{0} 37^{\prime} \mathrm{N}$ with land area of 77,818 $\mathrm{km}^{2}$ (Agboola, 1979). A high 103 percentage of the region lies within the tropical rainforest zone of Nigeria. Annual rainfall ranges 104 between $1400 \mathrm{~mm}$ and $4000 \mathrm{~mm}$ while mean temperature varies between $21-34^{\circ} \mathrm{C}$. Rainfalls 105 occur within the months of April to November while dry season lasts from December to March. 106 Soils are predominantly ferruginous tropical, typical of the variety found in intensively 107 weathered areas of basement complex formations in the rainforest zone of southwestern Nigeria 108 (Onyekwelu et al., 2008).

\section{Method of Data Collection}

110 Out of the sacred groves in southwestern Nigeria, four (Osun-Osogbo, Igbo-Olodumare, Idanre 111 Hills and Ogun-Onire) were purposefully selected based on prominence/significance, 112 accessibility and permission to conduct inventory. The selected groves covered three (Ekiti, 113 Ondo and Osun) of the six southwestern states. Two line transects of $1000 \mathrm{~m}$ each in length, 114 separated by a distance of at least $1000 \mathrm{~m}$ were laid approximately at the middle of each sacred 115 grove. Temporary sample plots of $40 \mathrm{~m} \times 20 \mathrm{~m}$ were laid on alternate sides along each transect at 116 every $250 \mathrm{~m}$ interval, giving 4 plots per transect, 8 per sacred grove and 32 for the study. Within

117 each sample plot, all living trees with $\mathrm{Dbh} \geq 10 \mathrm{~cm}$ were identified and their Dbh and total

118 heights measured. For tree sapling enumeration, a $10 \mathrm{~m} \times 10 \mathrm{~m}$ sub-plot was laid at the middle of 
119

120

121

122

123

124

125

126

$127 \quad R D=\frac{n_{i}}{N} \times 100$

each plot. All saplings (Dbh $>1.0 \mathrm{~cm}$ but $<10 \mathrm{~cm}$ ) were identified and their dbh measured. A $5 \mathrm{~m}$ $\times 5 \mathrm{~m}$ quadrant was laid within each sub-plot for seedlings (Dbh $<1.0 \mathrm{~cm}$ ) enumeration. Frequencies of identified seedling species were recorded.

\section{Data computation and analysis}

The following biodiversity indices were computed:

(i) Species relative density was computed as

Where: $\mathrm{RD}(\%)=$ species relative density; $\mathrm{ni}=$ number of individuals of species $\mathrm{i} ; \mathrm{N}=$ total number of all tree species in the entire community

131 equation 2.

$132 R D_{O}=\frac{\sum B a_{i} \times 100}{\sum B a_{n}}$

Where: $\mathrm{Ba}_{\mathrm{i}}=$ Basal area of individual tree belonging to species $\mathrm{i} ; \mathrm{Ba}_{\mathrm{n}}=$ Stand basal area

(iii) Importance Value Index (IVI): This was obtained using equation 3.

$135 \quad I V I=\frac{R D+R D_{O}}{2}$

136 (eqn. 3)

137 (iv) Sorensen's species similarity index between two sites was calculated using equation 4:

$$
S I=\left(\frac{2 C}{a+b}\right) \mathrm{X} 100
$$

139 Where: $\mathrm{C}=$ number of species at sites $\mathrm{a}$ and $\mathrm{b} ; \mathrm{a}, \mathrm{b}=$ number of species at sites $\mathrm{a}$ and $\mathrm{b}$.

(v) Species diversity index was calculated using the Shannon-Wiener diversity index (eqn. 5): 


$$
H^{\prime}=-\sum_{i=1}^{S} p_{i} \ln \left(p_{i}\right)
$$

142 Where: $H^{\prime}=$ Shannon-Wiener diversity index; $\mathrm{P}_{\mathrm{i}}=$ proportion of $\mathrm{S}$ made up of the $\mathrm{i}^{\text {th }}$ species, $\ln$

$$
\text { = natural logarithm }
$$

144 (vi) Shannon's maximum diversity index was calculated using eqn. 6:

$145 \quad \mathrm{H}_{\max }=\ln (\mathrm{S})$

146 Where: $\mathrm{H}_{\max }=$ Shannon's maximum diversity; $\mathrm{S}=$ Total number of species in the community.

147 (vii) Species evenness in each site was determined using Shannon's equitability $\left(\mathrm{E}_{\mathrm{H}}\right)($ eqn. 7):

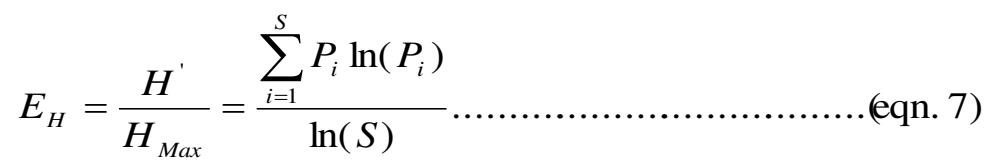

(viii) Margalef's index was calculated using the eqn. 8:

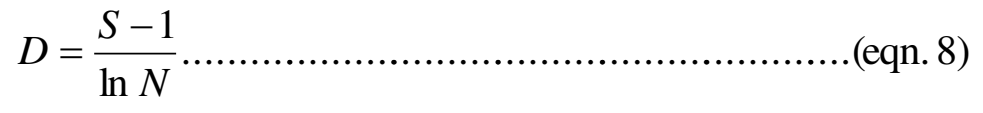

151 Where: $\mathrm{S}=$ number of species; $\mathrm{N}=$ number of individual

152 The five most dominant tree species in each sacred grove were selected for regeneration

153 assessment. Regeneration status was determined based on population sizes of seedlings, saplings

154 (Bhuyan et al. 2003; Khumbongmayum et al., 2006) and overstory trees. Good 155 regeneration:,seedlings > saplings > overstory trees; fair regeneration: seedlings $>$ or $\leq$ saplings $156 \leq$ adults; poor regeneration:, the species survives only in sapling stage, but no seedlings (saplings 157 may be $<$, > or = adults); if a species is present only at adult stage it is considered as not 158 regenerating (Khumbongmayum et al., 2006). Species is considered as 'new' (recruitment) if the 159 species has no adults and saplings but only seedlings. In this study, a species was considered 160 unique to a sacred grove if found only in that sacred grove in this study. Also, a species was 
161 considered endemic if it is only found in a sacred grove and never been reported in any forest site

162 in Southwestern Nigeria based on the information at our disposal.

\section{Results}

164 The overstories and understories of the sacred groves in this study were dominated by few tree 165 species. Results of species relative dominance revealed that seven tree species occupied between $166 \quad 66.06 \%$ and $85.69 \%$ of the overstories and $60.81 \%$ and $92.56 \%$ of the undertories of the sacred 167 groves (Tables 1 to 4 ). As few as 2 to 3 tree species could occupy over $50 \%$ of the sacred groves. 168 Hidergardia barterii alone occupied $65.09 \%$ of the overstory of Igbo-Olodumare (Table 2), 169 making it the most dominant species across the sacred groves in this study. At the understory 170 layer, Napoleona imperialis was the most dominant species, occupying $33.65 \%$ of the understory 171 of Idanre Hills grove (Table 1). No single species was dominant in all the four sacred groves 172 (both overstories and understories). Ceiba pentandra and Funtumia elastica were dominant in 173 the overstories of three of the four sacred groves. In most cases, the dominant tree species in the 174 overstory layer were not the dominant species in the understory of specific sacred grove, the only 175 except being Sterculia tragacantha and Cola hispida which were dominant in the overstory and 176 understory of Igbo-Olodumare and Osun-Osogbo sacred groves, respectively (Tables 2 and 4).

177 The dominant tree species also doubled as the important species as a result of their high IVI 178 (Table 1 to 4$).$

179 Number of tree families in the overstory and understory layers of the various sacred groves 180 varied from 19 to 29 and 15 to 25, respectively (Table 5). The understory of the sacred groves 181 had higher species richness (39 to 78) than the overstory layer (32 to 62), a situation that was 182 observed across all sacred grove (Table 5). Similarly, tree density at the understory layer (775 to 
$1831445 \mathrm{ha}^{-1}$ ) was much higher $(85.5 \%$ to $367.6 \%)$ compared to the density at the overstory layers

184 (309 to $417 \mathrm{ha}^{-1}$ ) of the sacred groves (Table 5). Shannon-Wiener diversity index ranged from

1851.8 to 3.46 at the overstory layer of the sacred groves and 2.65 to 3.55 at the understory (sapling)

186 layer.

187

188 Table 1: Important value index (IVI) for seven most important species in Idanre Hill 189 sacred grove

\begin{tabular}{cllllllll}
\hline S/N & \multicolumn{3}{c}{ Overstory } & \multicolumn{3}{c}{ Understory } \\
\cline { 2 - 8 } & Species & $\begin{array}{l}\text { RD } \\
(\boldsymbol{\%})\end{array}$ & $\begin{array}{l}\text { RDo } \\
(\boldsymbol{\%})\end{array}$ & $\begin{array}{l}\text { IVI } \\
\mathbf{( \% )}\end{array}$ & Species & $\begin{array}{l}\text { RD } \\
(\boldsymbol{\%})\end{array}$ & $\begin{array}{l}\text { RDo } \\
(\boldsymbol{\%})\end{array}$ & $\begin{array}{l}\text { IVI } \\
(\boldsymbol{\%})\end{array}$ \\
\hline 1 & Ceiba pentandra & 3.03 & 21.98 & 12.51 & Napoleona imperialis & 14.91 & 33.65 & 24.28 \\
2 & Cassia siamen & 15.15 & 9.18 & 12.17 & Alcormanis difformis & 14.04 & 26.14 & 20.09 \\
3 & Cola gigantean & 7.58 & 11.33 & 9.45 & Combretum racemosum & 8.77 & 5.86 & 7.32 \\
4 & Alstonia boonei & 1.52 & 14.66 & 8.09 & Lecaniodiscus cupanioides & 5.26 & 5.93 & 5.60 \\
5 & Antiaris africana & 3.03 & 8.81 & 5.92 & Albizia zygia & 3.51 & 3.53 & 3.52 \\
6 & Funtumia elastic & 5.05 & 4.08 & 4.57 & Dialum guinensis & 2.63 & 4.36 & 3.49 \\
7 & Berlinia grandiflora & 6.57 & 2.24 & 4.40 & Baphia nitida & 2.63 & 3.34 & 2.99 \\
\hline
\end{tabular}

190

191

192 Table 2: Important values index (IVI) for seven most important species in Igbo-Olodumare $193 \quad$ sacred grove

\begin{tabular}{lllllllll}
\hline \multicolumn{3}{c}{ Overstory } & \multicolumn{5}{c}{ Understory } \\
\hline S/N & Species & $\begin{array}{l}\text { RD } \\
(\%)\end{array}$ & $\begin{array}{l}\text { RDo } \\
(\boldsymbol{\%})\end{array}$ & $\begin{array}{l}\text { IVI } \\
(\boldsymbol{\%})\end{array}$ & Species & $\begin{array}{l}\text { RD } \\
(\boldsymbol{\%})\end{array}$ & $\begin{array}{l}\text { RDo } \\
(\boldsymbol{\%})\end{array}$ & $\begin{array}{l}\text { IVI } \\
(\boldsymbol{\%})\end{array}$ \\
\hline 1 & Hidergardia barterii & 62.07 & 65.09 & 63.58 & Spondias pinnata & 22.78 & 29.44 & 26.11 \\
2 & Ricinodendron heudelotii & 4.21 & 7.45 & 5.83 & Combretum racemosum & 13.92 & 17.48 & 15.70 \\
3 & Sterculia tragacantha & 5.75 & 2.13 & 3.94 & Hidergadia barterii & 8.86 & 20.93 & 14.89 \\
4 & Ceiba pentandra & 2.68 & 4.13 & 3.41 & Sterculia tragacantha & 7.59 & 12.45 & 10.02 \\
5 & Funtumia elastic & 3.07 & 1.17 & 2.12 & Trichilia welwitschii & 6.33 & 7.58 & 6.96 \\
6 & Spondias mombin & 3.45 & 2.31 & 2.88 & Cissus araloides & 5.06 & 3.13 & 4.09 \\
7 & Ficus sycomorus & 0.38 & 3.41 & 1.90 & Olax subscorpioidea & 6.33 & 1.55 & 3.94 \\
\hline
\end{tabular}

194 
Table 3: Important values index (IVI) for even most important species in Ogun-Onire sacred grove

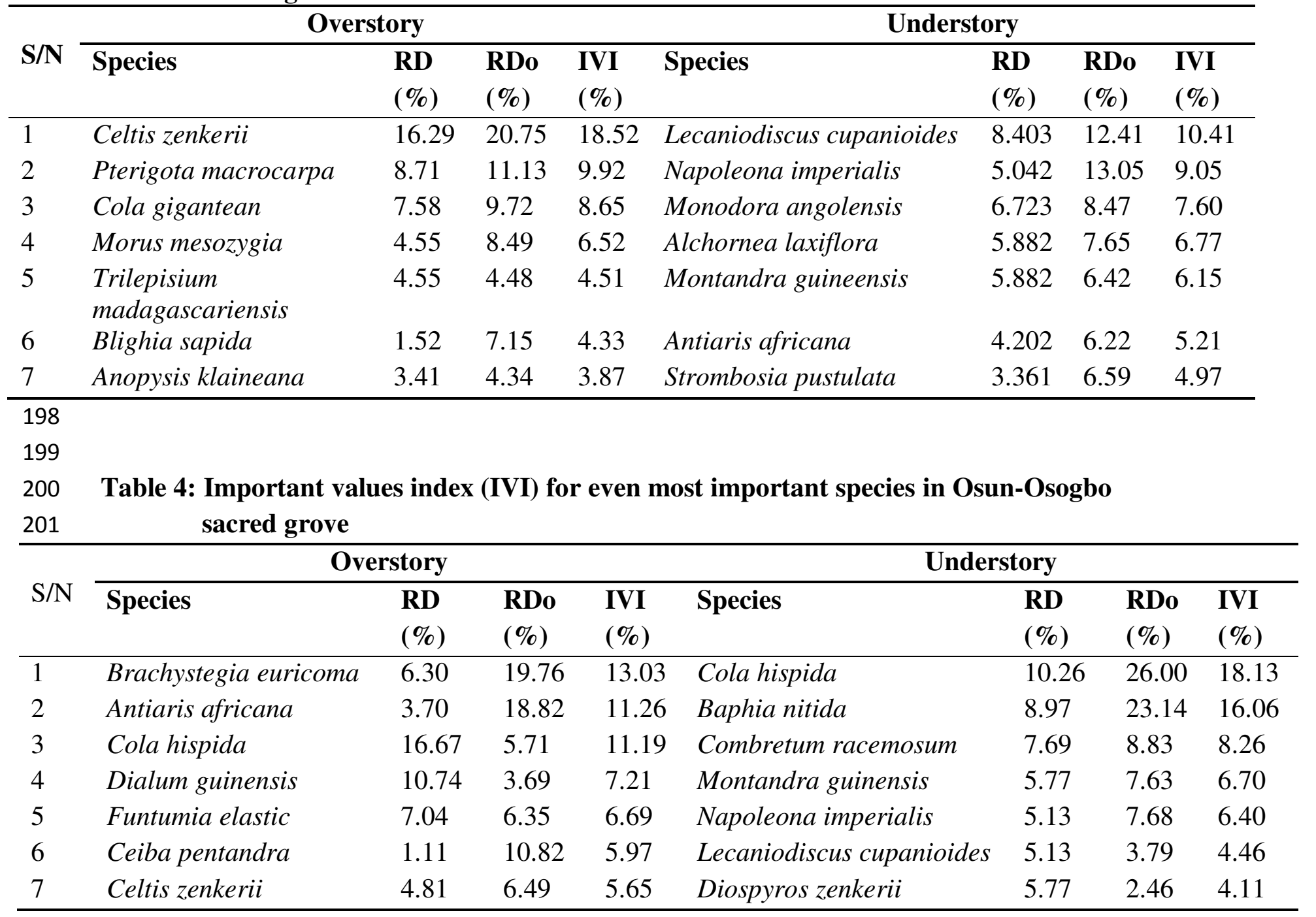


Table 5: Summary of understory and overstory biodiversity indices of the sacred groves

\begin{tabular}{|c|c|c|c|c|}
\hline \multirow[t]{2}{*}{ Biodiversity indices } & \multicolumn{4}{|c|}{ Sacred groves } \\
\hline & $\begin{array}{l}\text { Osun- } \\
\text { Osogbo }\end{array}$ & $\begin{array}{l}\text { Igbo- } \\
\text { Olodumare }\end{array}$ & $\begin{array}{l}\text { Idanre } \\
\text { Hills }\end{array}$ & $\begin{array}{l}\text { Ogun- } \\
\text { Onire }\end{array}$ \\
\hline \multicolumn{5}{|c|}{ Overstory Layer } \\
\hline Number of Families & 27 & 19 & 26 & 29 \\
\hline Number of Species & 50 & 31 & 43 & 62 \\
\hline Number of Trees $\mathrm{Ha}^{-1}$ & 417 & 408 & 309 & 408 \\
\hline Shannon-Wiener Diversity Index & 3.19 & 1.8 & 3.25 & 3.46 \\
\hline Species Evenness & 0.84 & 0.52 & 0.86 & 0.85 \\
\hline Simpson Concentration $(\lambda)$ & 0.07 & 0.4 & 0.06 & 0.05 \\
\hline Species Richness (Margalef Index) & 8.05 & 5.57 & 7.94 & 10.24 \\
\hline \multicolumn{5}{|c|}{ Understory Layer } \\
\hline Number of Families & 17 & 15 & 20 & 25 \\
\hline Number of Species & 55 & 39 & 73 & 78 \\
\hline Number of Understory $\mathrm{Ha}^{-1}$ & 775 & 835 & 1445 & 903 \\
\hline Shannon-Wiener Diversity Index & 3.55 & 2.65 & 3.26 & 3.51 \\
\hline Species Evenness & 0.63 & 0.36 & 0.36 & 0.43 \\
\hline Simpson Concentration & 0.96 & 0.90 & 0.92 & 0.95 \\
\hline Species Richness (Margalef Index) & 8.12 & 5.65 & 9.90 & 11.31 \\
\hline
\end{tabular}

203

204

205

206

207

208

209

210

211

Species similarity between pairs of sacred groves varied from $57.69 \%$ to $82.35 \%$ in the overstory and $24.66 \%$ to $75.47 \%$ in the understory (Table 6). Species similarity between pairs of groves was higher in the overstory than the understory. In the Overstory, species similarity was highest between Idanre Hills and Osun-Osogbo (82.35\%) and lowest between Igbo-Olodumare and Osun-Osogbo (57.69\%). In the understory layer, the highest similarity index was between OgunOnire and Osun-Osogbo (75.47\%) while the lowest value was between Igbo-Olodumare and Ogun-Onire $(24.66 \%)$.

\section{Table 6: Species Similarity}

\begin{tabular}{lcc}
\hline Sorenses Similarity Index & Overstory $(\boldsymbol{\%})$ & $\begin{array}{c}\text { Understory } \\
(\boldsymbol{\%})\end{array}$ \\
\hline Idanre Hill and Igbo Olodumare & 66.67 & 31.03 \\
Idanre Hill and Ogun-Onire & 79.31 & 65.45 \\
Idanre Hill and Osun-Ososgbo & 82.35 & 50.00 \\
Igbo-Olodumare and Ogun-Onire & 72.73 & 24.66 \\
Igbo-Olodumare and Osun-Osogbo & 57.69 & 40.00 \\
Ogun-Onire and Osun-Osogbo & 80.00 & 75.47 \\
\hline
\end{tabular}


212 In all the sacred groves, tree dbh distribution followed inverse-J shape (Figure 1). Majority of the

213 trees in the four groves fell within $10 \mathrm{~cm}-20 \mathrm{~cm}$ dbh class, followed by $20 \mathrm{~cm}-30 \mathrm{~cm}$ class; only

214 few trees were above $100 \mathrm{~cm}$ (Figure 1). The highest stand density across the four groves was

215 recorded in the lowest dbh class of 10-20 cm, making this class the highest contributor of stand

216 density to total density for each grove. Stand density consistently decreased with increase in dbh

217 (Figure 1).

218 Species regeneration status was studied using the 5 dominant species in each grove. Except 219 Dialum guinensis and Funtumia elastica whose regeneration was poor because they were not 220 found at seedling stage, other species in Osun-Osogbo recorded higher number of seedlings 221 followed by saplings and overstory trees (Figure 2), indicating that the species had good 222 regeneration status. In Igbo-Olodumare grove, three of the five dominant tree species had good 223 to fair regeneration while Funtumia elastica and Ceiba pentandra displayed poor regeneration 224 status (Figure 3). The regeneration of Ceiba pentandra, Alstonia boonei and Cassia siamen at 225 Idanre Hills were considered poor due to the absence of seedlings of the species and the lower 226 density of saplings compared to overstory trees (Figure 4). The other two species had good 227 regeneration. Figure 5 presented a picture of poor regeneration status at Ogun-Onire grove. Out 228 of five dominant species, three species were not represented at seedling stage and had lower 229 density of saplings compared to overstory trees. The regeneration of Trilepson madagascariensis 230 and Pterygota macrocarpa was fair. Figure 6 revealed that Ogun-Onire grove had the highest 231 recruitment potential, followed by Osun-Osogbo. Both Igbo-Olodumare and Idanre Hills groves 232 displayed low recruitment potential. Tree species that occurred at only one site were regarded as 233 unique to that site and denoted with "+". Tree species common to at least two sacred groves 234 were denoted with "o". Results on Table 7 revealed that among the four sacred groves, Ogun- 
235 Onire grove had the highest number of unique species (24), which was followed by Osun236 Osogbo grove with a total of 14 unique species (Table 7). Both Igbo-Olodumare and Idanre Hills 237 sacred groves had 9 unique species each. Tree species endemic in the sacred groves are presented 238 on Table 8. For example, Hildegardia barterii, Piptadeniastrum africanum and Irvigia smithii 239 were the tree species found only in Igbo-Olodumare. Angylocarlyx oligophyllus was found only 240 in Osun-Osogbo. Anopyxis klaineana, Tetrapleura tetraptera, Draceana arborea, Lovoa 241 trichilioides, Lannea welwitschii and Drypetes gossweileri were tree species found only in 242 Ogun-Onire grove.

\section{Discussion}

244 The understory, which comprises a major component of plant diversity, contributes to the 245 structural complexity of forests and is important in the dynamics and functioning of the forest 246 ecosystem (Royo and Carson, 2005; Su et al., 2019). Where the understory is species poor, the 247 sustainability of the forest is threatened, since there may not be enough seedlings to replace the 248 overstory trees when they die or are removed. The absence of or poor seedling or sapling 249 population may imply lack of or poor regeneration or temporal cessation in recruitment. Except 250 at Igbo-Olodumare, the Shannon-Wiener diversity indices at the understories of sacred groves 251 (Osun-Osogbo, Idanre Hills and Ogun-Onire) in this study were generally similar to those of 252 their respective overstories. This implies that species diversity in the understories and overstories 253 of three groves are similar. The diversity indices of our sacred groves are higher or similar than 254 what were reported for some primary forests, degraded forests and sacred groves in Nigeria 255 (Lawal and Adekunle, 2013; Onyekwelu and Olusola, 2014). The higher diversity index at the 256 understory of Igbo-Olodumare grove than its overstory is an indication of higher species

257 diversity at its understory. Johnston (2019) reported a significantly higher Shannon diversity 
258 index in the understory of hardwood forests in northern Michigan and Wisconsin, USA 259 compared to the overstory.

260 The future community structure and regeneration status of a species could be predicted from the 261 relative proportion of understory species in the total populations of various species in the forest 262 (Khumbongmayum et al., 2006). The higher number of species at the understory layers (range: $26339-78$ ) compared to the overstory layers (range: 32 - 62) of our sacred groves is an indication of 264 the contribution of the understory to biodiversity conservation and a confirmation that the 265 understory of sacred groves could be more species rich than the overstory layer. Our results 266 imply that tree regeneration in the four sacred groves is healthy, which is similar to the view 267 expressed by Khumbongmayum et al. (2006). The sacred groves in our study had higher number 268 of understory species compared to what was reported by Onyekwelu and Olusola (2014). 269 Similarly, Khumbongmayum et al. (2006) reported higher understory species (seedlings and 270 sapling) than overstory trees in four sacred groves in Manipur, India. Higher number of 271 understory species was also reported by Johnston (2019) for hardwood forests of northern 272 Michigan and Wisconsin, USA. Another indication of good regeneration in our sacred groves is 273 the much higher tree density in the understory layer than the overstory layer, which is in 274 consonance with some published results (Khumbongmayum et al., 2006; Onyekwelu and 275 Olusola, 2014; Johnston (2019). Density of regenerating medicinal plants in sacred groves of 276 central western Ghats, India were almost twice that of forest reserves (Boraiah et al., 2003).

277 In most cases, the number of seedlings was higher than number of saplings and overstory species 278 in our sacred groves. Ballabha et al. (2013) opined that regeneration is considered good if the 279 number of seedlings > number saplings > number of overstory trees; fair if the number of 
seedlings $>$ number saplings $\leq$ number of overstory trees; which were the situations in our groves. The differences in the densities of seedlings, saplings and overstory trees among the four sacred groves in this study may be due to the interactive influences of an array of biotic and abiotic factors, especially anthropogenic factors and natural phenomena. Studies have shown that anthropogenic activities is increasing in sacred groves in Nigeria (Onyekwelu and Olusola, 2014; Adeyanju, 2020).

Currently, the Nigerian forest ecosystems are faced with lots of challenges. Illegal logging, urbanization and clearance of forests for agriculture had negatively impacted on the extent of the forests and the population of valuable tree species. Some Nigerian forest reserves have undergone various degrees of degradation from both illegal and legal loggers, which has led to reduction in species richness (Aruofor, 2001; Onyekwelu et al., 2008; Olayinka et al., 2018). Recent studies (Onyekwelu and Olusola, 2014; Adeyanju, 2020) have revealed that sacred groves are gradually being encroached upon. Species regeneration is usually negatively affected by forest degradation. Therefore, forestry professionals are confronted with the task of finding the best approach to enhance regeneration of valuable tree species.

Tree species regeneration depends on the maturity and diameter structure of their population (Bhuyan et al. 2003). Characteristics of the forest floor, micro-environmental conditions under the forest canopy and anthropogenic activities influence tree regeneration. Tree diameter distribution is an indication of how well the forest is regenerating and is making use of site resources (Rao et al., 1990). The tree dbh distribution curves of the sacred groves in this study followed the inverse-J shape typical of natural tropical rainforests (Onyekwelu et al., 2008) and some sacred groves (Khumbongmayum et al., 2006; Onyekwelu and Olusola, 2014; Sarkar and 
Devi, 2014). Inverse-J dbh distribution is an indication of good regeneration status and healthy forest ecosystem (Sarkar and Devi, 2014). It suggests an evolving or expanding population, climax or stable type of population in forest ecosystem, indicating that the forest harbours a 306 growing population (Mishra et al., 2005; Sahu et al., 2012). We share similar opinion with 307 Khumbongmayum et al. (2006) that the presence of established seedlings of dominant species is 308 an indication of their excellent recruitment which also suggests that the prevailing environmental 309 conditions of the study site are favourable for their establishment stage. The high recruitment 310 recorded in the sacred groves may be attributed to disposal by birds and other animals that bring 311 new seeds or fruits to the groves. In addition, the high recruitment could be attributed to disposal 312 by worshipers, visitors and tourists to the groves.

313 Conservation and maintenance of biodiversity in natural forest ecosystem can only be guaranteed 314 through regeneration. Our observation is that the overall tree regeneration status in our sacred 315 groves is satisfactory showing "good" and "fair" regeneration, though few tree species fell under 316 "poor" and "not" regenerating status. Successful regeneration of a tree species depends on its 317 ability to produce large number of seedlings and the ability of seedlings and saplings to survive 318 and grow, situations that were evident in our sacred groves. The good species regeneration 319 recorded in the sacred groves could be attributed to high level of access restrictions imposed by 320 their managements (chief priests, community leaders, etc). For instance, nobody dared enter 321 Ogun-Onire grove without the permission of the chief priest as the grove is believed to be sacred 322 and the habitation of the gods. Also, there are taboos and myths that are feared by the people, 323 which prevents their entrance into the groves. With these restrictions, anthropogenic activities 324 that could destroy seedlings are reduced thereby enhancing regeneration and recruitment 325 potentials. However, some of these appear to be changing or could change given some recent 
326 developments in sacred grove management in Nigeria. Activities (rituals, initiations, festivals, 327 and other ceremonies) in Nigerian sacred groves have increased in recent times, which has led to 328 an alarming high influx of people into the groves. It is estimated that between 130,000 and 329150,000 people visit Osun-Osogbo grove for annual festival celebration (Aleshinloye. and 330 Maruyama, 2015; Adeyanju, 2020). Due to this high influx of people, seedlings and saplings are 331 sometimes trampled upon and their survival is affected. Oftentimes, ritual rites and sacrifices 332 may involve ground clearing and ground fires by priests and devotees. Since individual species 333 in young stages are more vulnerable to any kind of environmental stress and anthropogenic 334 disturbance, sapling and seedling densities in the sacred groves are adversely affected, thereby 335 negatively influencing species regeneration and recruitment. In addition, lot of seeds in the soil 336 seed bank could be destroyed during ground clearing or burning, which could affect their 337 germination and result in limited or no regeneration.

338 Sacred groves could serve as reservoir for preserving unique and endangered tree species. In this 339 study, some tree species were discovered to exist only in one sacred grove. For instance, Hildegardia barteri was endemic to Igbo-Olodumare, Lovoa trichilioides was unique to Ogun341 Onire sacred grove. No known study has reported the presence of any of these species in any 342 forest reserves in Southwestern Nigeria. Also, some tree species that are not found in protected 343 forests in Nigeria (e.g. Akure forest reserve, Queen's plot, Omo forest reserve) (Lawal and 344 Adekunle, 2013, Salami and Akinyele, 2018, Omomoh et al., 2019) were encountered in some of 345 the sacred groves. The presence of these unique tree species directly or indirectly contributes to 346 the welfare and stability of the local environment. The prevalence of the unique species clearly 347 indicates the potential of sacred groves for conservation of important tree species. Onyekwelu 348 and Olusola (2014) reported that about 32\% of the species encountered in Osun-Osogbo and 
349 Igbo-Olodumare sacred groves are among the tree species classified as endangered by 350 FORMECU (1998).

\section{Conclusion and recommendation}

352 Sacred groves could harbour high regeneration and promote tree species conservation, especially 353 in forest understory layer. Osun-Osogbo, Idanre Hills, Igbo-Olodumare and Ogun-Onire sacred 354 groves harboured some unique and important tree species. High regeneration and recruitment 355 status maintained in all the sacred groves in this study were achieved using taboos, cultural and 356 traditional methods. These methods could be incorporated in managing forest reserves in

357 Southwestern Nigeria. Also, conservative efforts should be made to avert the extinction of 358 endemic species in the sacred groves.

360 List of Abbreviations

361 Dbh - Diameter at breast height

362 RD - Relative Density

$363 \mathrm{n}_{\mathrm{i}}-$ number of individual of species

$364 \mathrm{~N}-$ Total number of all tree species in the entire community

$365 \mathrm{RD}_{0}-$ Relative Dominance

$366 \mathrm{Ba}_{\mathrm{i}}-\mathrm{Basal}$ area of individual tree belonging to a species

$367 \quad \mathrm{Ba}_{\mathrm{n}}-$ Stand basal area

368 IVI - Important Value Index

369 SI - Similarity Index

$370 \quad H^{\prime}$ - Shannon-Wiener diversity index

$371 \mathrm{~S}-$ Total number of species in the community 
$372 \mathrm{E}_{\mathrm{H}}-$ Species evenness

373 D - Marhalef's index

374

375 Declarations

376 Ethics approval and consent to participate

$377 \quad$ Not applicable

378

379 Consent for publication

380 Not applicable

381

382 Availability of data and material

383 The datasets used and/or analysed during the current study are available from the corresponding 384 author on reasonable request.

385

386 Competing interests

387 The authors declare that they have no competing interests

388

$389 \quad$ Funding

390 All aspects of this research including design of the study, data collection, data processing and 391 analysis and data interpretation were founded by Alexander von Humboldt (AvH) Foundation, 392 Bonn, Germany 
395 Conceptualization and design: J.C. Onyekwelu, B.Stimm and R. Mosandl.

396 Funding acquisition: J.C. Onyekwelu, R. Mosandl and B. Stimm.

397 Methology and Data collection: J.C. Onyekwelu, A. Lawal, A.D. Agbelade and B. Stimm.

398 Data Analyses and Interpretation: A. Lawal and J.C. Onyekwelu.

399 Manuscript Writing (Original draft): A. Lawal and J.C. Onyekwelu.

400 Manuscript Writing (Review \& editing): J.C. Onyekwelu, B. Stimm and R. Mosandl

401 Reading and approval of the final manuscript: All authors

402 Acknowledgement

403 This study was undertaken using the financial support from the Alexander von Humboldt (AvH)

404 Foundation under the Research Group Linkage Programme. The authors are grateful to the AvH

405 for the support.

406

407 Authors' information (optional)

408 Prof. J. C. Onyekwelu: Professor of Silviculture and Forest Management, Department of

409 Forestry and Wood Technology, Federal University of Technology, Akure, Nigeria.

410 Dr. A. Lawal - Forest Genetics and Tree Breeding Unit, Department of Forestry and Wood

411 Technology, Federal University of Technology, Akure, Nigeria

412 Prof. R. Mosandl-Professor of Silviculture, Chair of Silviculture, Technical University of

413 Munich, Freising, Germany

414 Prof. B. Stimm - Academic Director and ecologist, Chair of Silviculture, Technical University of

415 Munich, Freising, Germany

416 Dr. A. D. Agbelade - Forest Inventory and Management Unit, Department of Forestry and

417 Wildlife, Ekiti State University, Ado-Ekiti, Nigeria 


\section{Footnotes}

References

Adeyanju SO (2020) Drivers of biodiversity conservation in sacred groves: a comparative study

of three sacred groves in south-west Nigeria. M.Sc thesis, University of British Columbia, Canada, 98pp.

427

428

429

430

Agboola SA (1979) An Agricultural Atlas of Nigeria, Oxford University Press, Nigeria. Pp. 248

Aruofor R (2001) Forestry Outlook Studies in Africa (FOSA): Nigeria. Ministry of Natural Resources and Tourism. http://www.fao.org/tempref/docrep/fao/004/ab592e/ab592e00.pdf (Accessed on 12/03/2020), 31pp.

Aleshinloye D, Maruyama N (2015) Solidarity at the Osun Osogbo Sacred Grove a UNESCO world heritage site. Journal of Tourism Planning and Development. 13(3): 274-291

Ballabha R, Tiwari JK, Tiwari P (2013) Regeneration of tree species in the sub-tropical forest of alaknanda valley, Garhwal Himalaya, India. For. Sci. Pract. 15, 89-97

Barnes BV, Zak DR, Denton SR, Spurr SH (1997) Forest ecology (4th ed.). New York, NY: John Wiley and Sons.

Bhagwat SA, Rutte C (2006) Sacred groves: Potentials for biodiversity management. Frontiers in ecology and the Environment, 4: $519-524$.

Bhuyan P, Khan ML, Tripathi RS (2003) Tree diversity and population structure in undisturbed and human-impacted stands of tropical wet evergreen forest in Arunachal Pradesh, Eastern Himalayas India. Biodivers. Conserv. 12(8): 1753-1773. 
441 Boraiah KT, Vasudeva R, Bhagwat SA, Kushalappa CG (2003) Do informally anaged sacred

442

443

444

445

446

447

448

449

450

451

452

453

454

455

456

457

458

459

460

461

462

groves have higher richness and regeneration of medicinal plants than state-managed reserve forests? Current Science, 84: 804 - 808.

Chastain RA, Currie WS, Townsend PA (2006) Carbon sequestration and nutrient cycling implications of the evergreen understory layer in Appalachian forests. Forest Ecology and Management 231: 63-77.

Ikyaagba ET, Amonum JI, Okwoche S (2019) Tree Species Composition and Diversity of IpinuIgede Sacred Forest in Oju Local Government Area of Benue State, Nigeria. Journal of Agriculture and Ecology Research International 18(3): 1-10.

FORMECU (1998) Forest Resources Study, Nigeria. Revised National Report Volume 2 prepared for FORMECU by Beak and Geomatics International.

Greene DF, Zasada JC, Sirois L, Kneeshaw D, Morin H, Charron I. et al. (1999). A review of the regeneration dynamics of North American boreal forest tree species. Can. J. For. Res. 29, 824-839.

Helms JA (1998) The Dictionary of Forestry. The Society of American Foresters, 210 pp.

Johnston J, Rodriguez R (2019) Overstory and Understory Species Composition and Diversity in UNDERC Closed-Canopy Hardwood Forests BIOS 35502-01: Practicum in Environmental Field Biology. Available at https://underc.nd.edu/assets/338767/fullsize/johnston 2019.pdf (Accessed 2/6/2020).

Khan ML, Khumbongmayum AD, Tripathi RS (2008) The sacred groves and their significance in conserving biodiversity an overview. International Journal of Ecology and Environmental Science. 34(3): 277-291. 
Khumbongmayum AD, Khan ML, Tripathi RS (2006) Biodiversity conservation in sacred groves of Manipur, northeast India: population structure and regeneration status of woody species. Biodiversity and Conservation, 15:2439-2456. DOI 10.1007/s10531-004-6901-0

Kokou K, Adjossou K, Kokutse AD (2008) Considering sacred and riverside forests in criteria and indicators of forest management in low wood producing countries: The case of Togo. Ecological Indicators, 8, 158-169.

Lawal A, Adekunle VAJ (2013) A Silvicultural Approach to Volume Yield, Biodiversity and Soil Fertility Restoration of Degraded Natural Forest in South West Nigeria. International Journal of Biodiversity Science, Ecosystem Service and Management. 9(3): 201-214.

Lexerod N, Eid T (2005) Recruitment models for Norway spruce, scots pine, birch and other broadleaves in young growth forests in Norway. Silva Fenn. 39, 391-406.

Mishra BP, Tripathi OP, Laloo RC (2005) Community characteristics of a climax subtropical humid forest of Meghalaya and population structure of ten important tree species. Tropical Ecology 46: 241-251.

Olayinka CI, Lawal A, Adekunle VAJ (2018) Consequence of Timber Exploitation on Tree Species Diversity and Livelihood of Communities Bordering Eda Forest Reserve, Ekiti State, Nigeria. Journal of Forestry Research and Management, 15(3): 118-136

Omomoh B, Adekunle V, Lawal A, Akinbi O (2019) Tree species diversity and regeneration potential of soil seed bank in Akure forest reserve, Ondo state, Nigeria. Taiwania 64(4): 409416.

Onyekwelu JC, Olusola JA (2014) Role of Sacred Grove in In-situ Biodiversity Conservation in Rainforest Zone of South-western Nigeria. Journal of Tropical Forest Science. 26(1):5-15. 
Onyekwelu JC, Mosandl R, Stimm B (2008) Tree species diversity and soil status of Primary and Degraded Tropical Rainforest Ecosystems in South-Western Nigeria. Journal of Tropical Forest Science 20(3): 193-204.

Rao P, Barik SK, Pandey HN, Tripathi RS (1990) Community Composition and tree Population Structure in a Sub-Tropical Broad-leaved Forest along Distance gradient. Vegetation 88:151162.

Royo AA, Carson WP (2005) On the formation of dense understory layers in forests worldwide: consequences and implications for forest dynamics, biodiversity, and succession. Canadian Journal of Forest Research 36: 1345-1362

Sahu SC, Dhal NK, Mohanty RC (2012) Tree species diversity, distribution and population structure in a tropical dry deciduous forest of Malyagiri hill ranges, Eastern Ghats, India. Tropical Ecology, 52: 163-168.

Salami KD, Akinyele AO (2018) Floristic composition, structure and diversity distribution in Omo biosphere reserve, Ogun State, Nigeria. Ife Journal of Science vol. 20(3): 639-648.

Sax DF (2002) Equal diversity in disparate species assemblages: A comparison of native and exotic woodlands in California, Global Ecology and Biogeography. 11:49 -57.

Saxena AK, Singh JS (1984) Tree population structure of certain Himalayan forest associations and implications concerning their future composition. Vegetation 58: 61-69.

Svenning JC (2000) Small canopy gaps influence plant distribution in the rain forest understory. Biotropica 32: 252-261.

Su X, Wang M, Huang Z, Fu S, Chen HYH (2019) Forest understorey vegetation: colonization and the availability and heterogeneity of resources. Forests 2019, 10, 944, 17pp. 
507 Tchouto MGP, De Boer WF, De Wilde J, Vander LJG (2006) Diversity patterns in the flora of 508 the Campo-Ma'an rain forest, Cameroon: do tree species tell it all? Biodiversity and $509 \quad$ Conservation 15: 1353-1374.

511 Table 7: Unique tree species in the study area

\begin{tabular}{|c|c|c|c|c|c|}
\hline $\mathrm{S} / \mathrm{N}$ & Name of Species & $\begin{array}{c}\text { Osun- } \\
\text { Osogbo }\end{array}$ & $\begin{array}{c}\text { Igbo- } \\
\text { Olodumare }\end{array}$ & $\begin{array}{c}\text { Idanre } \\
\text { Hills }\end{array}$ & $\begin{array}{l}\text { Ogun- } \\
\text { Oonire }\end{array}$ \\
\hline 1 & Afzelia africana & - & - & - & + \\
\hline 2 & Albizia ferruginea & o & o & o & o \\
\hline 3 & Albizia lebbeck & o & - & - & o \\
\hline 4 & Albizia zygia & o & - & o & o \\
\hline 5 & Alchornea laxiflora & - & - & - & + \\
\hline 6 & Alchornia cordifolia & - & - & + & - \\
\hline 7 & Alstonia boonei & - & - & o & o \\
\hline 8 & Amphiman pterocarpoides & - & + & - & - \\
\hline 9 & Angylocalyx oligophyllus & + & - & - & - \\
\hline 10 & Anopyxis klaineana & - & - & - & + \\
\hline 11 & Anthocleista djalonensis & - & - & + & - \\
\hline 12 & Anthonotha macrophylla & - & - & - & + \\
\hline 13 & Antiaris africana & o & - & o & - \\
\hline 14 & Baphia nitida & $\mathrm{o}$ & - & o & - \\
\hline 15 & Berlinia grandiflora & - & - & o & o \\
\hline 16 & Blighia sapida & o & o & o & o \\
\hline 17 & Bombas buonopozense & - & - & - & + \\
\hline 18 & Brachystegia eurycoma & + & - & - & - \\
\hline 19 & Brachystegia kennedyi & - & - & - & + \\
\hline 20 & Brachystegia nigerica & o & o & - & - \\
\hline 21 & Canarium schweinfurthii & - & - & - & + \\
\hline 22 & Cassia siamen & - & - & + & - \\
\hline 23 & Ceiba pentandra & o & o & o & o \\
\hline 24 & Celtis mildbraedii & o & o & - & o \\
\hline 25 & Celtis philippensis & - & - & - & + \\
\hline 26 & Celtis zenkerii & o & o & - & o \\
\hline 27 & Chrysophyllum albidum & - & - & o & o \\
\hline & Cleistopholis patens & - & + & - & - \\
\hline & Cola acuminata & - & - & - & + \\
\hline & Cola gigantea & - & - & o & o \\
\hline & Cola hispida & o & o & o & o \\
\hline
\end{tabular}


32 Cola millenii

33 Cordia millenii

34 Dialium guineense

35 Diospyros dendo

36 Diospyros mobutensis

37 Discoglypremna caloneura Distemonanthus

38 benthamianus

39 Dracaena arborea

40 Dracaena marginata

41 Drypetes gossweileri

42 Drypetes oblongifolia

43 Entandrophragma angolense Entandrophragma

44 cylindricum

45 Ficus sycomorus

46 Ficus exasperate

47 Ficus mucoso

48 Funtumia elastica

49 Gliricidia sepium

50 Gmelina arborea

51 Hanoa cleniana

52 Hildegardia barteri

53 Holarrhena floribunda

54 Hunteria Umbellata

55 Irvingia smithii

56 Ixora guinensis

57 Khaya grandifoliola

58 Lannea welwitschii(Hiern)

59 Lecaniodiscus cupanioides

60 Lovoa trichilioides

61 Malachanta alnifolia

62 Mallotus oppositifolius

63 Manilkara obovata

64 Mansonia altissima

65 Margaritaria discoidea

66 Massularia acuminate

67 Melachanta alnifolia

68 Milicia excels

69 Milletia thonningii

70 Monodora myristica

71 Monodora tenuifolia o

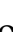

o

$-$

o

$+$

o

o

$-$

$+$

$-$

$-$

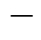

$-$

o

o

$+$

$+$

$+$

$-$

$-$

$-$

$-$

$+$

$-$

$-$

o

$-$

$-$

$-$

o

$-$

o

$+$

$+$

$-$

o

o

$-$ o

$-$

o

o

$-$

$-$

$+$

$-$

$+$

$-$

$+$

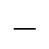

O

O

O

$-$

$-$

$-$

$-$

$-$

$+$

$-$

$-$

o

$+$

0

$+$

$+$

$+$

$-$

o

$-$

$-$

o

o

$-$

$+$ 
72 Morinda lucida

73 Morus mesozygia

74 Myrianthus arboreus

75 Napoleonaea imperialis

76 Newbouldia laevis

77 Piptadeniastrum africanum

78 Pterocarpus mildbraedii

79 Pterygota macrocarpa

80 Pycnanthus angolensis

81 Rauvolfia vomitoria

82 Ricinodendron heudelotii

83 Rothmannia longiflora

84 Rothmannia whitfieldii

85 Spathodea campanulata

86 Spondias mombin

87 Spondias pinnata

88 Sterculia oblonga

89 Sterculia rhinopetala

90 Sterculia tragacantha

91 Strombosia fasae

92 Strombosia pustulata

93 Tabernaemontana coronaria

94 Terminalia superba

95 Tetrapleura tetraptera

96 Trema orientalis

97 Trichilia monadelpha

98 Trichilia welwitschii

99 Trilepisium madagascariense

100 Triplochiton scleroxylon

101 Voacanga africana

102 Zanthoxylum zanthozaloides

\begin{tabular}{|c|c|c|c|}
\hline- & - & + & - \\
\hline- & - & $\mathrm{o}$ & o \\
\hline- & - & - & + \\
\hline+ & - & - & - \\
\hline o & - & o & - \\
\hline- & + & - & - \\
\hline- & - & + & - \\
\hline- & $\mathrm{o}$ & $\mathrm{o}$ & o \\
\hline- & - & - & + \\
\hline- & - & + & - \\
\hline $\mathrm{o}$ & $\mathrm{o}$ & - & o \\
\hline $\mathrm{o}$ & $\mathrm{O}$ & - & - \\
\hline+ & - & - & - \\
\hline $\mathrm{o}$ & - & - & o \\
\hline- & $\mathrm{O}$ & $\mathrm{o}$ & - \\
\hline $\mathrm{o}$ & - & $\mathrm{o}$ & o \\
\hline $\mathrm{o}$ & $\mathrm{o}$ & $\mathrm{o}$ & o \\
\hline- & - & - & + \\
\hline- & o & o & - \\
\hline+ & - & - & - \\
\hline- & - & - & + \\
\hline+ & - & - & - \\
\hline- & - & $\mathrm{o}$ & o \\
\hline- & - & - & + \\
\hline- & - & + & - \\
\hline o & - & o & - \\
\hline o & o & o & o \\
\hline o & - & - & o \\
\hline o & - & - & o \\
\hline- & - & - & + \\
\hline- & + & - & - \\
\hline
\end{tabular}




\section{Figures}
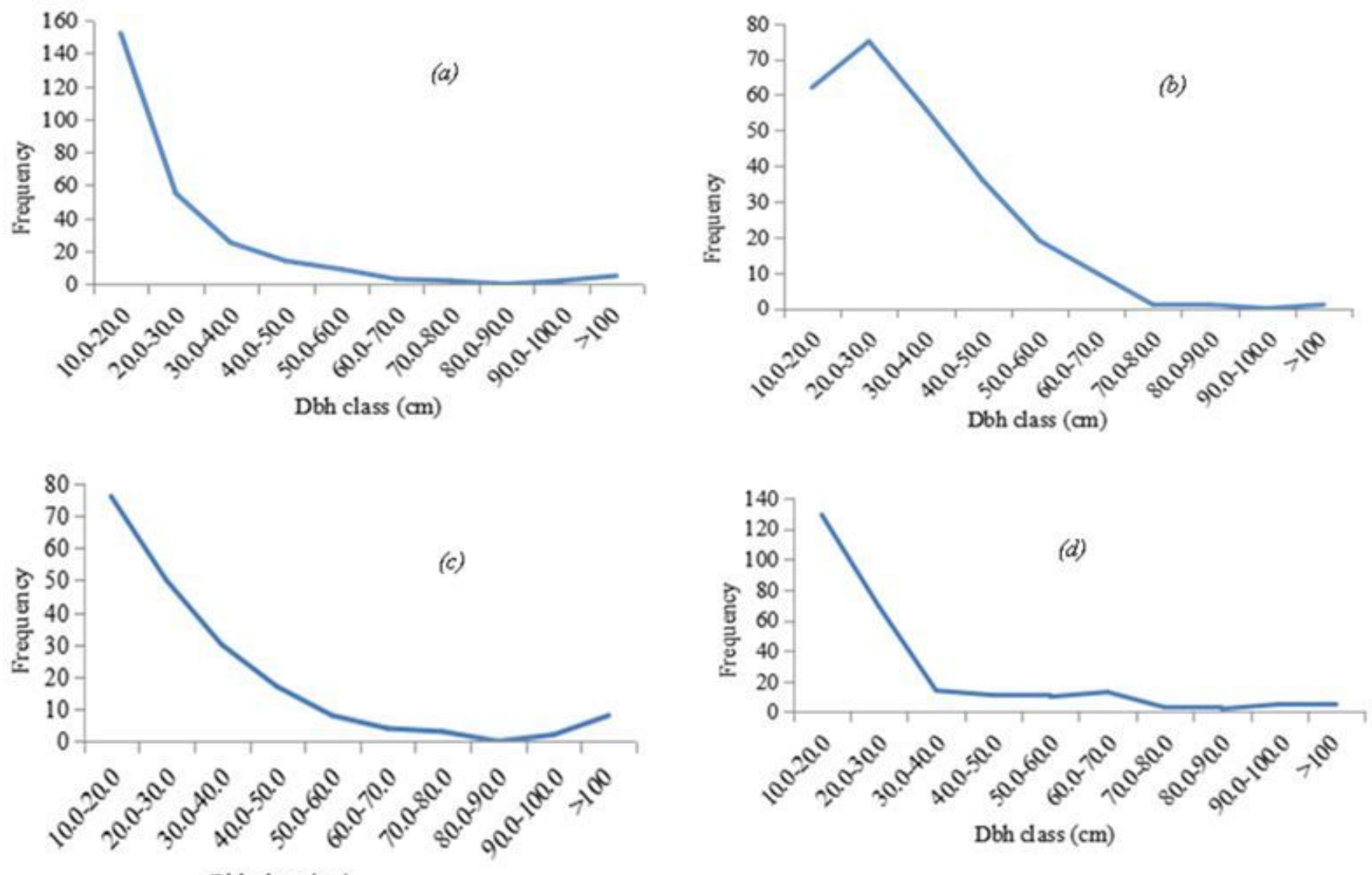

Key: (a) Osun Osogbo, (b) Igbo Olodumare, (c) Idanre hills and (d) Ogun Onire

\section{Figure 1}

Tree diameter distribution in the selected sacred groves 

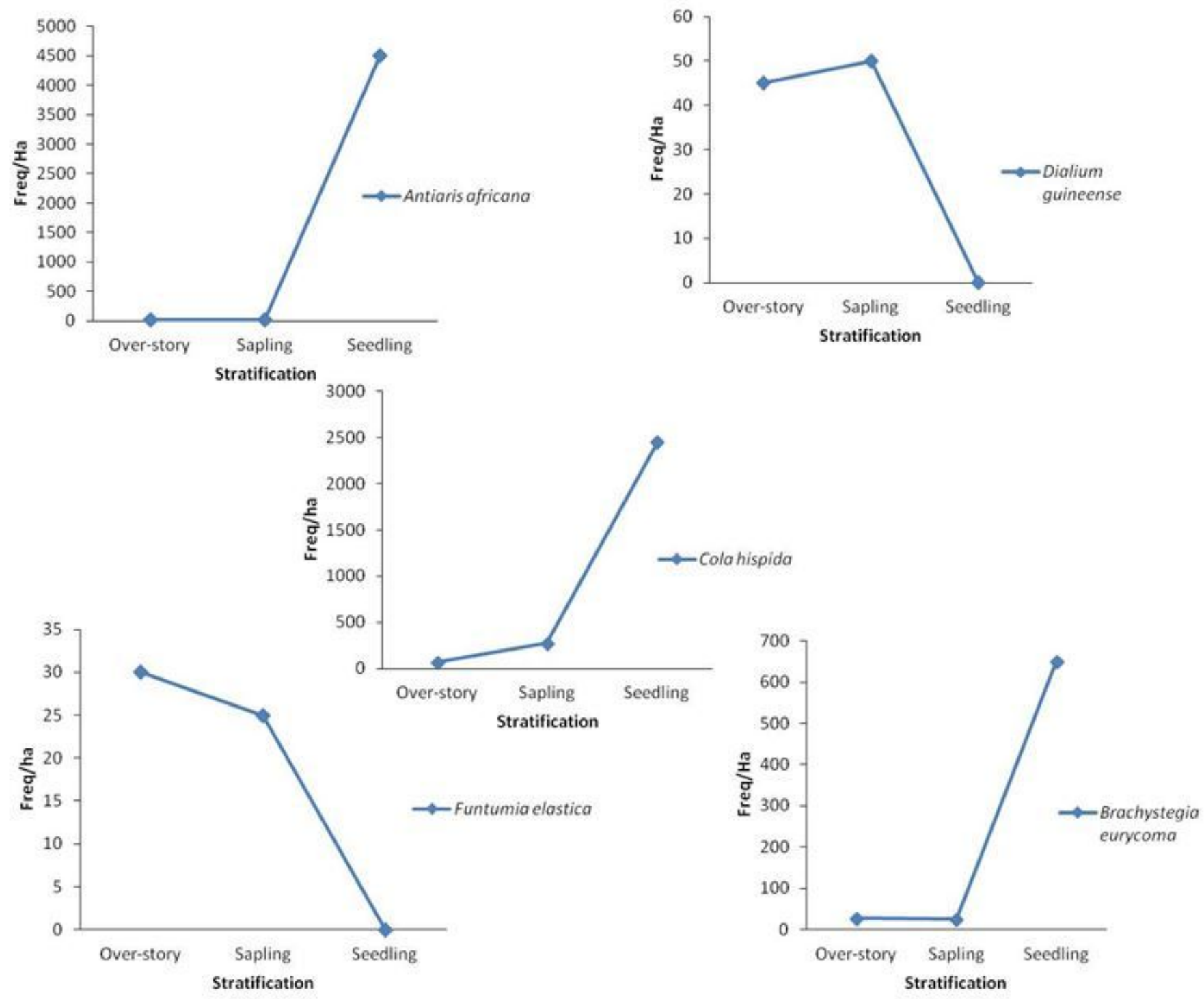

\section{Figure 2}

Regeneration status of five (5) most dominant species in the Osun-Osogbo sacred grove 

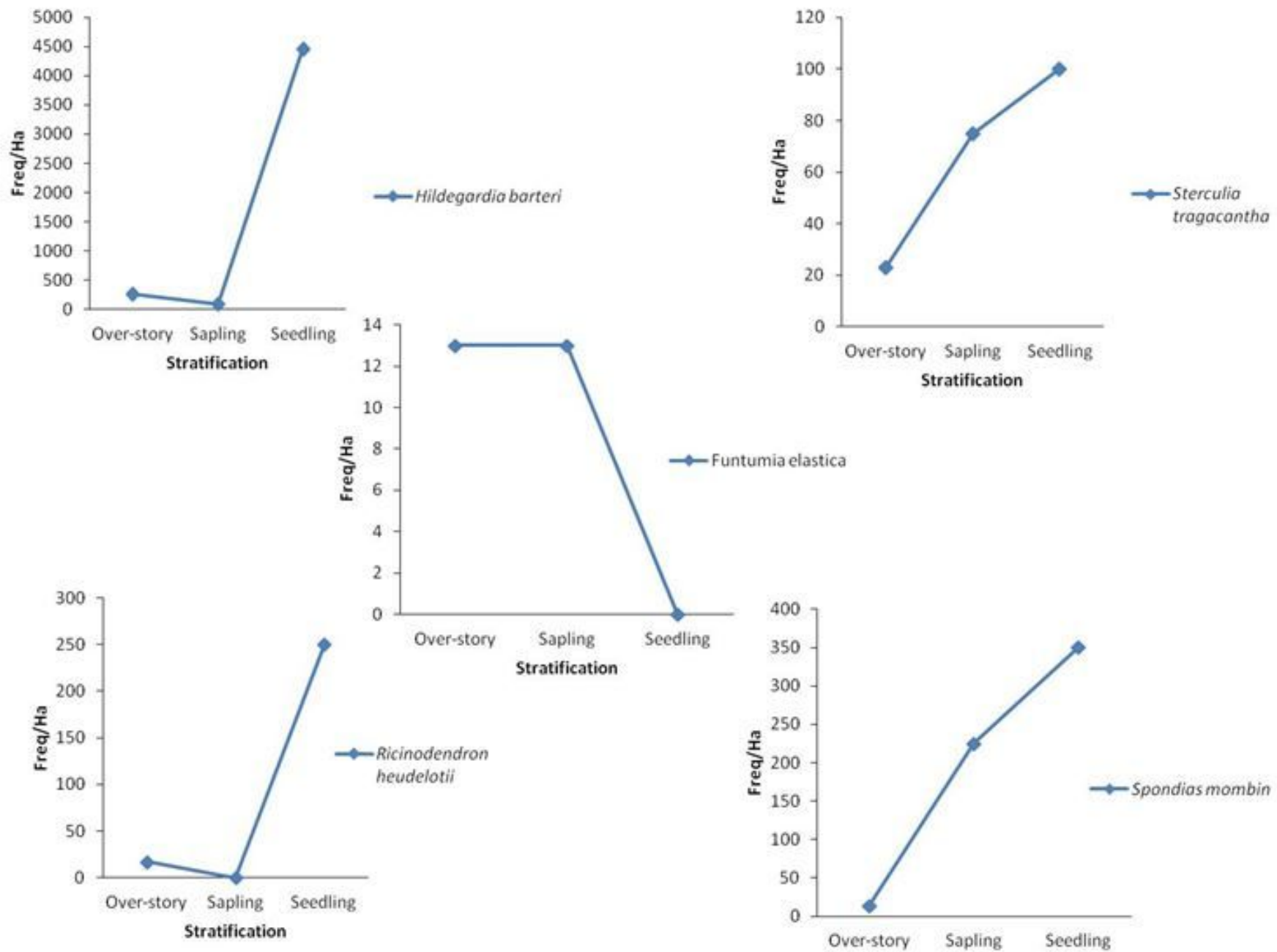

Figure 3

Regeneration status of five (5) most dominant species in Igbo-Olodumare sacred grove 

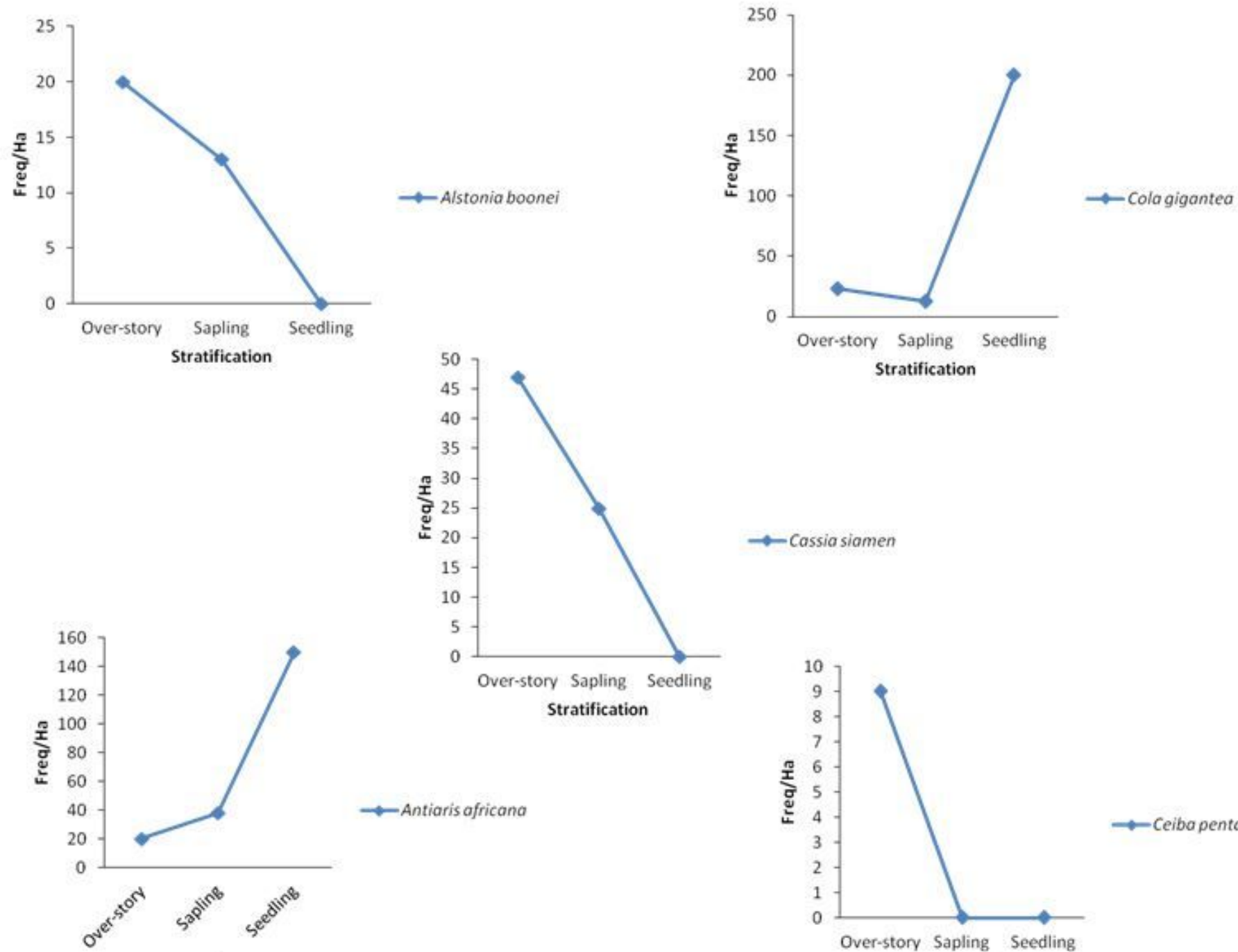

Stratification

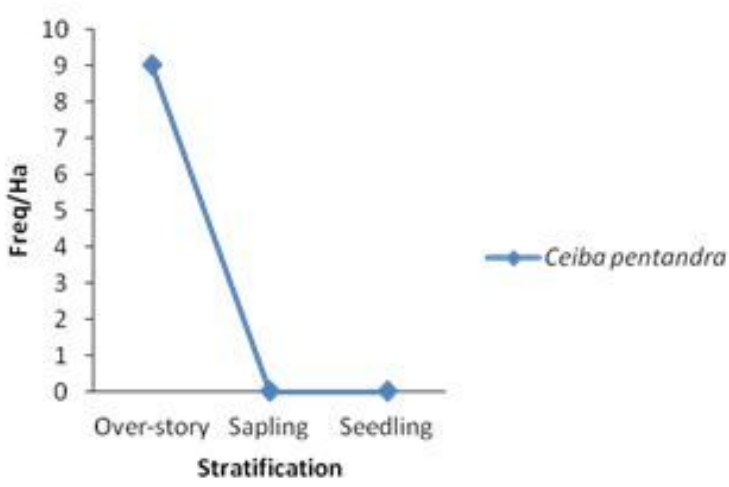

\section{Figure 4}

Regeneration status of five (5) most dominant species in Idanre Hills sacred grove 


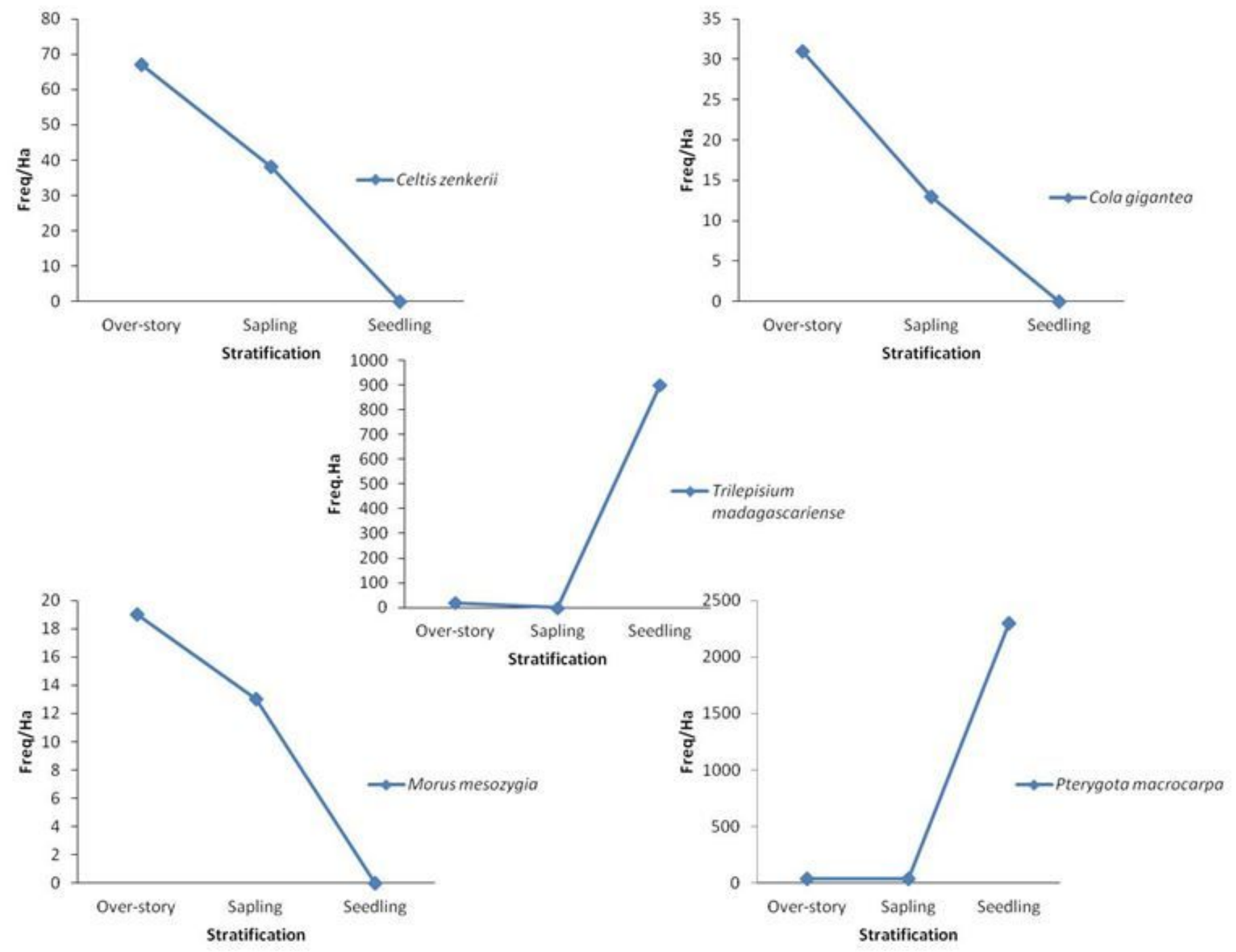

Figure 5

Regeneration status of five (5) most dominant species in Ogun-Onire sacred grove 


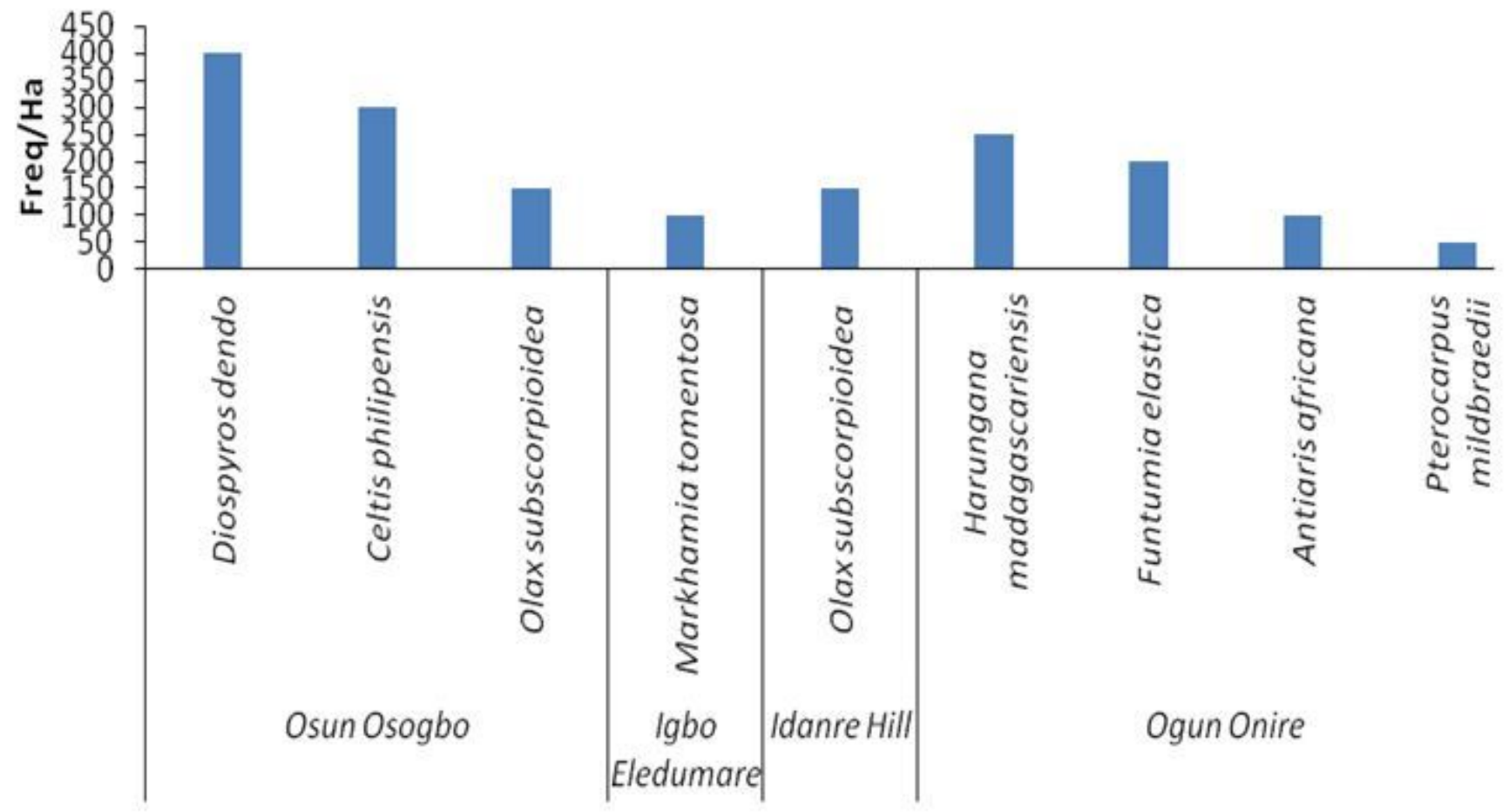

Sacred Groves with Recruited Species

Figure 6

Recruitment potential of sacred groves in SW Nigeria 